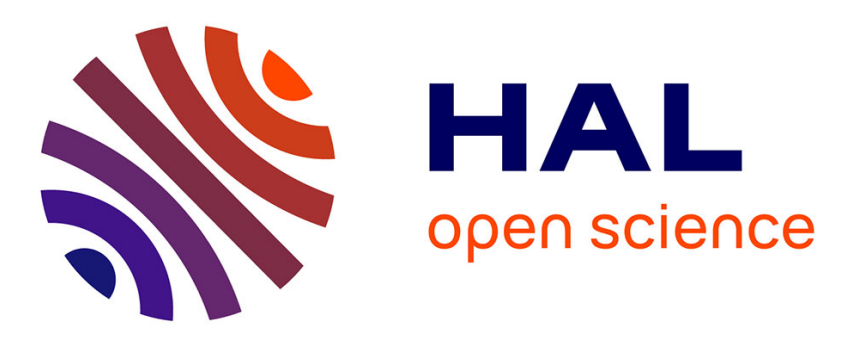

\title{
Effect of Cognitive Demand on Visual Field Performance in Senior Drivers with Glaucoma
}

Viswa Gangeddula, Maud Ranchet, Abiodun Akinwuntan, Kathryn Bollinger, Hannes Devos

\section{- To cite this version:}

Viswa Gangeddula, Maud Ranchet, Abiodun Akinwuntan, Kathryn Bollinger, Hannes Devos. Effect of Cognitive Demand on Visual Field Performance in Senior Drivers with Glaucoma. American Congress of Rehabilitation Medicine, Oct 2017, Atlanta, GA, United States. . hal-01721071

\section{HAL Id: hal-01721071 \\ https://hal.science/hal-01721071}

Submitted on 1 Mar 2018

HAL is a multi-disciplinary open access archive for the deposit and dissemination of scientific research documents, whether they are published or not. The documents may come from teaching and research institutions in France or abroad, or from public or private research centers.
L'archive ouverte pluridisciplinaire HAL, est destinée au dépôt et à la diffusion de documents scientifiques de niveau recherche, publiés ou non, émanant des établissements d'enseignement et de recherche français ou étrangers, des laboratoires publics ou privés. 
CENTER 1' 1 Laboratory for Advanced Rehabilitation Research in Simulation (LARRS), Department of Physical Therapy and Rehabilitation Science,

The University of Kansas

University of Kansas Medical Center, Kansas City, KS, USA, ${ }^{2}$ Univ Lyon, IFSTTAR, Lyon, France, ${ }^{3}$ Department of Ophthalmology, Medical College of Georgia, Augusta University, Augusta, Georgia, USA

\section{Background}

$>$ Glaucoma leads to peripheral visual field loss.

$>$ Visual field loss may affect safe driving.

$>$ Safe driving is determined by intact visual field, cognitive capacity, and cognitive demand.

$>$ The relationship between cognitive demand and visual field in drivers with glaucoma is unclear.

\section{Purpose}

$>$ To compare the effect of cognitive demand on functional visual field between drivers with glaucoma and control drivers.

\section{Methods}

$>20$ drivers with open-angle glaucoma and 13 age- and sexmatched controls.

$>$ Visual field performance was evaluated under different conditions of cognitive demand using an interactive, desktop driving simulator (Figures 1 \& 2).

$>$ Primary outcomes: Number of correct responses and response time on visual field.

\section{hdevos@kumc.edu http://larrs.kumc.edu}

$>$ No significant differences between the glaucoma and healthy control groups in demographics and clinical measures.

$>$ Glaucoma group performed worse on mean deviation both eyes and standard pattern deviation right eye from Humphrey Visual Field Analyzer.

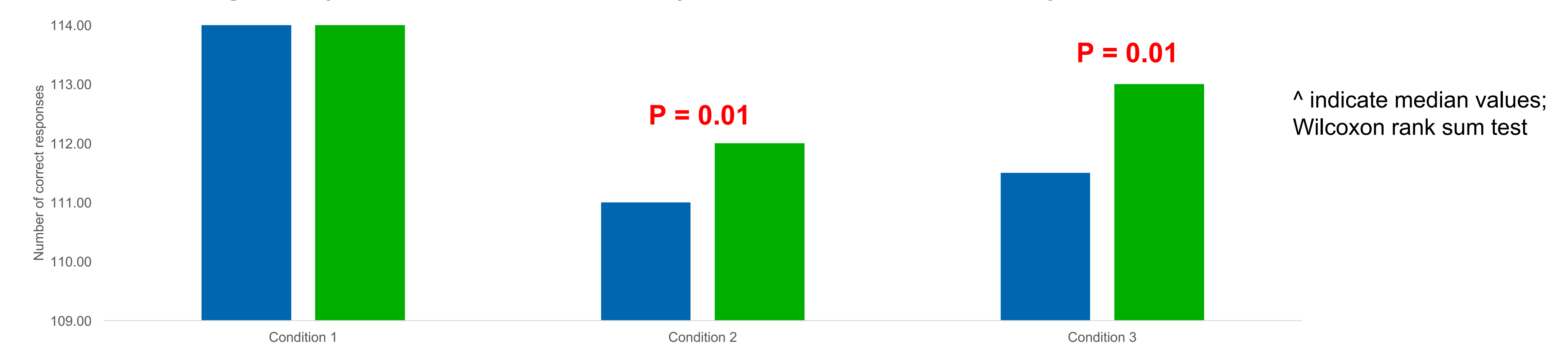

Figure 3. Comparison of correct responses in static (condition 1), dynamic (condition 2), and active driving (condition 3).

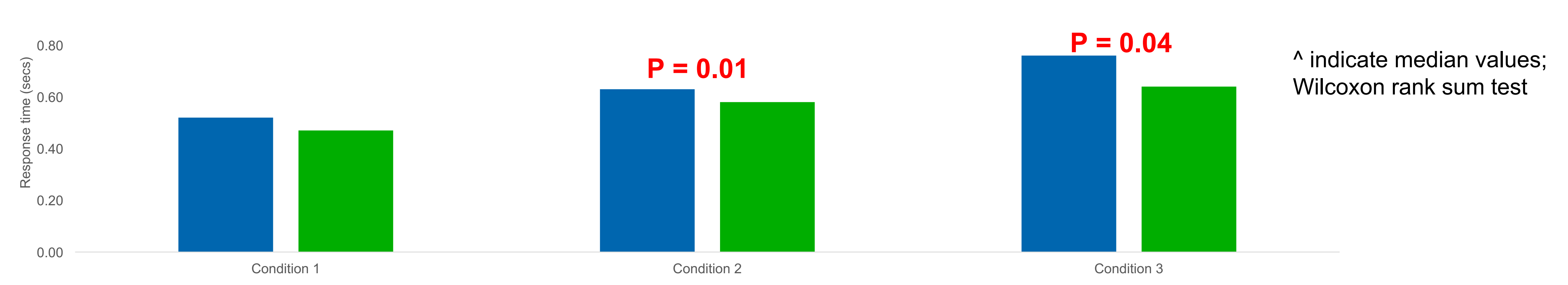

Figure 4. Comparison of response time static (condition 1), dynamic (condition 2), and active driving (condition 3).

$>$ Significant decrease in correct response time and response time with increased cognitive demand (Wilcoxon Signed Rank, $p<0.05$ ).

$>$ Glaucoma group responded less accurately and slower in the dynamic visual field task without active driving (condition 2 ) and with active driving (condition 3 ) compared with healthy controls $(p<0.05)$ (Figures 3 and 4$)$.

$>$ Increase in complexity disproportionally affected visual field in glaucoma (Wilcoxon rank sum, $p<0.05)$.

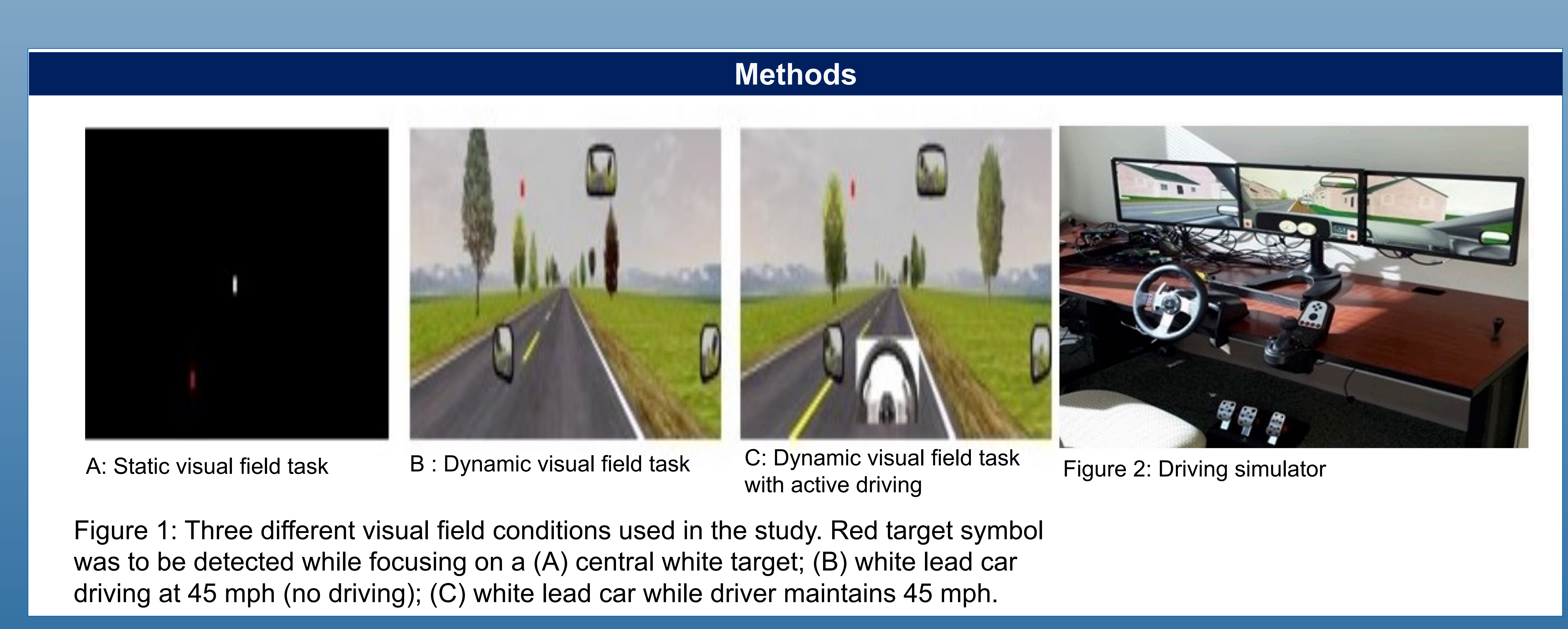

\section{Discussion}

$>$ Increase in cognitive demand reduced the functional visual field performance in both groups.

$>$ However, drivers with glaucoma performed worse on the visual field task, especially when dynamic visual flow was added.

$>$ Driving assessments should consider the participants' physiological visual field, their cognitive capacity, and the cognitive demand of the task to fully appreciate the impact of any visual field loss performance.

\section{Acknowledgement}

$>$ This study was funded in part by the Fight for Sight / Prevent Blindness America Public Health Award and a pilot grant by the Culver Vision Discovery Institute.

$>$ The authors acknowledge the contributions of Dr. Sumner Fishbein, and Dr. Lane Ulrich.

References
1. Ball KK, Roenker DL, Bruni JR. Developmental
changes in attention and visual search throughout
adulthood. Advances in psychology (1990) 69:489-
508.
2. Gangeddula, V., et al., Effect of Cognitive Demand on
Functional Visual Field Performance in Senior Drivers
with Glaucoma. Frontiers in Aging Neuroscience,
2017. 9(286).

